\title{
Critical agency in the post-apartheid education system
}

\section{Nazir Carrim}

\begin{abstract}
This paper looks at critical agency in the South African education system. There has been a consistent linking of critical thinking with critical agency under apartheid, and that this was constructed by a 'critical struggle' (Touraine, 1985) against apartheid domination.

However, this changed significantly in the post-apartheid moment, where compliance with the newly elected government is emphasised, and could be viewed in terms of 'positive struggles' (Touraine, 1986). These, however, limit critical agency in the post-apartheid formation. There is, nonetheless, evidence of critical agency being enacted in the post-apartheid education system. The importance of highlighting those forms of critical agency is crucial in order to enhance social justice in the post-apartheid educational system and society. This paper also links critical agency in the post-apartheid situation with the postcolonial and postmodern conditions because such conditions affect the possibilities of critical agency not only in South Africa but more generally.
\end{abstract}

\section{Introduction}

This paper focuses on critical agency in the South African educational system, and I do so from the lens of social movements. Part of the reason for the focus adopted here is the argument that for critical agency to be considered as such, it would need to lead to an alternative order, and not just be at the level of individual's oppositional actions, whether such actions are discursive or in social practices. Another reason for the focus on critical agency and social movements in this paper is because of what seems to be a decline in critical agency in the post-apartheid educational system. However, such a view presupposes several things: from relations between structures and agents; what constitutes alternatives in transformative terms; to individual and collective forms of action. In many ways as well, these presuppositions are being called to question because they point to shifts not only from apartheid to the post-apartheid formation but also to shifts from colonial to postcolonial situations (see Mbembe, 2001) and from modern to postmodern conditions (see Hall, 1992), locally and globally, and the kind of social actions they enable. 
In the first section of this paper I engage with some of the issues related to critical thinking and critical agency by way of clarification mainly. Since the focus in this paper is more on looking at critical agency in the context of social movements, I am more concerned in this paper with looking at what types of critical agency in the South African education system results in what forms of social movement actions and how to make sense of these in theoretical terms. In order to do so I use Touraine's (1981 and 1985) characterisation of social movements and apply this to the South African educational context.

In the second part of this paper, I engage with some of approaches to understanding social movements and link these to the typology which Touraine provides. In this section, the increasing acknowledgement that social movements are more pluralised and dispersed currently seem to suggest that they are more characterised by 'positive struggles' in Touraine's terms. Such 'positive struggles' are also shown to be linked significantly to the material conditions of postmodernity. In this section of the paper I also discuss how such 'positive struggles' have manifested themselves in the post-apartheid situation.

In the third section of this paper I focus on Equal Education, a post-apartheid educational movement in order to demonstrate the complexities of critical agency and social movements in the post-apartheid situation.

In the last section of this paper, I focus on the implications for critical agency in the postmodern/postcolonial situation and show that 'front politics' and pluralised and dispersed forms of social actions, which may or may not converge into collective forms of actions, are more predominant currently. This requires a reorientation to understanding what may be regarded as collective forms of action. The implications this has for understanding current struggles in post-apartheid South Africa are also highlighted.

It is important to keep in mind that the focus in this paper is on critical agency in education in post-apartheid South Africa. Although, it is not possible to engage in such a discussion without also looking at social movements in postapartheid South Africa more broadly, my focus in this paper is specifically on education. Thus, whilst I engage with some theories about social movements, and these cover various sectors of societies and in varying contexts, my concern in this paper is on the education sector specifically, and on critical agency in the post-apartheid educational system. 
At the same time, it should also be noted that, in this paper I do not cover various movements in the post-apartheid educational system which may be construed as social movements as well, but focus instead on one educational social movement, Equal Education, as an illustrative example of the complexities of critical agency in the post-apartheid educational context.

At the outset it is also important for me to clarify that due to the limitations of space in this paper I am unable to enter into in-depth and detailed discussions about the various issues I raise in this paper. In this paper, I only use Touraine's characterisation of 'critical and positive struggles'. I do not provide a full account of Touraine's theory. I also look at some theories about social movements. I do so mainly in the context of Touraine's characterisation of 'critical and positive struggles' and in order to link Touraine with other social movement theories. I also do not cover all the issues that pertain to postmodernity, post-colonialism or the post-apartheid situation. As such, in this paper I open up the issues for further debate and discussion, and I suggest a possible terrain in which such a conversation may be taken further. The limitation of this paper and the brevity with which I deal with the issues I raise in this paper should be kept in mind.

\section{Critical agency and critical thinking}

The idea of critical agency in education came to the fore in stark terms with the advent of critical theory and its applications to education, which drew upon and critiqued early Marxism (see for example, Usher, 1996). The discourses of reproduction and resistance theories of schooling were noted for their contributions to raising awareness of the how schools are superstructurally manipulated to reproduce capitalist orders, and in the wake also significantly informed a critical view of schooling and schools (Aronowitz and Giroux, 1986). From Bowles and Gintis' (1976) theory of the economic reproduction roles of schooling and its correspondence with the socialisation into hierarchies of capitalist relations; Bourdieu's (Bourdieu, 1976) account of the ways in which schools act as conservative forces and reproduce and privilege middle class cultural capital; to Gramsci's (see Aronowitz and Giroux, 1986) view of the political hegemonic role schools play in reproducing state hegemony as ideological apparatuses of state; reproduction theories of schooling point importantly to the need to be critical about what schooling does in capitalist society. 
Critical agency in this view, then, implied being critical of the ways in which schools reproduce, maintain and legitimise capitalism (see Aronowitz and Giroux, 1986; and Dale, Esland and MacDonald, 1976) and taking action in order to work towards a more just social order. How this was possible began to be debated seriously given the overwhelming tendency towards structuralism in such reproduction theories which seem to have reduced any possibility for agency, critical or otherwise (see also Aronowitz and Giroux, 1986 in this regard).

It is in the debates with reproduction theories that resistance theories which foregrounded agency began to increase in significance. Willis' (1981) argument that all forms of reproduction, in themselves, entail agency was a crucial point in these debates. What Willis pointed out was that human beings - agents - in structures like schools are not just automatically reproduced into unequal capitalist orders, but through their own agency enable such reproduction to occur. Through his research with all boys' working class schools in England, Willis showed how through their own meaning making and choices the boys in such schools landed up being reproduced in working class jobs. Reproduction, then, could not be viewed as divorced from agency, and recognising how people as agents make meaning of the structures they inhabit, the ways in which they negotiate such meanings and the types of strategies they adopt to deal with such contexts were important to understand not only with regard to how schooling works, but also the dialectical relationship between structures and agency (see also Aronowitz and Giroux, 1986 in this regard).

It is also important to point out here that within critical theory and Marxism the importance of holding together the macro-sociological and microsociological dimensions of social lives, as well as structure and agency are central to the relational thinking that Marxism and critical theory employ. For Marxism and critical theory there is a dialectical inter-relationship between the macro-sociological and micro-sociological dimensions, and between structure and agency. The one is not without the other. They entail each other, influence each other and construct a dynamic between them that is dialectical (see Craib, 1984). The importance of this cannot be stressed sufficiently because it is the basis for the construction of the problematic of critical agency. Understanding how macro-sociological forces construct, enable and constrain agency and the ways in which agency at any level impacts on both the micro-sociological and macro-sociological dimensions of social life are crucial to understand. 
The contours of these debates reverberated in South Africa. Kallaway's (1986) seminal work Apartheid and Education put forward a set of papers which applied both reproduction and resistance theories of schooling in order to analyse apartheid education. Christie and Collins (1986) article in this book applied reproduction theories in analysing Bantu Education, and convincingly showed how Bantu Education was integral to the reproduction of the apartheid order. Molteno's (1987) article applied resistance theories of schooling to show how Western Cape students exercised agency in their resistance to apartheid and apartheid education. As such, considerations of reproduction and resistance in education in South Africa, as well as entering into debates about the relations between structures and agency, were similar to education discourses elsewhere in the world.

Critical agency in the terms of critical theory and reproduction and resistance theories of schooling, then, means, firstly, being critical of the workings of capitalism, and as such requires critical thinking and critical awareness. Secondly, such critical thinking, it is implied, should also lead to critical agency against capitalism domination. The linking of critical thinking with critical agency against capitalism is a consequence of the Marxist maxim which states that it is not enough to merely interpret the world, but also to change it (see Mark and Engels, 1969). Influenced by Marxist analyses, critical theory and reproduction and resistance theories of schooling, thus, understood critical agency as changing capitalist orders. As such, such analyses highlighted the need for collective actions and not just individual actions since changing capitalist orders necessitate collective actions which go beyond individual actions.

In South African education, however, this was a bit more complicated because of the system of apartheid. Being critical of apartheid education meant being critical of both its capitalist and racist forms of domination. Thus, reproduction and resistance theory applications in South Africa indicated how apartheid education reproduced both capitalism and racism. In such applications apartheid was viewed as a system of racial capitalism, not just as a system of capitalism (see Kallaway, 1986). These applications to South African education were significant because they also opened up nonreductionist accounts of both capitalism more generally, and apartheid more specifically (see also Wolpe, 1988).

A caveat is in order here. Whilst Marxism and critical theory were significant in bringing attention to the importance of being critical of social orders and 
the need to exercise collective actions to change such orders, it would be incorrect to suggest that being critical and the idea of critical thinking originated with Marxism and critical theory. Critical thinking was indeed present in Plato's account of Socrates' Dialogues in The Republic (Plato, 1920), early educationists such as Dewey (1910) also pointed to the importance of education developing critical thinking, and debates within positivism (see Hahn, Carnap and Neurath, 2001) and interpretivism (see Hospers, 1990), which predate critical theory, are also replete with rigorous theoretical argument and critical thinking. In South Africa, as the Kallaway (1986) seminal book poignantly also indicates, there were types of critical thinking and critical agency that existed in pre-apartheid, colonial times and under slavery.

What does, however, seem to be different with Marxism and critical theory is the linking of critical thinking with critical agency in order to change the material relations and bases of capitalist orders. It is, thus, not coincidental that Marxism and critical theory have been significant in informing social movements in the $20^{\text {th }}$ century, from antiracism, feminism and working class struggles, throughout the world (see also Hall, 1992). However, it should be pointed out here that whilst Marxism and critical theory significantly influenced the development of such social movements, these social movements also differed significantly with Marxism and critical theory by pointing to other forms of domination and oppression - forms of domination and oppression that were not reducible to capitalism - and, thereby also had the effect of pluralising forms of critical agency and social movements (see also Hall 1992 in this regard).

My purpose in the above is to clarify some of the assumptions that are at work in accounts of social movements. It is not my intention to go into depth about the many debates and nuances about issues of structures and agency, individual and collection actions and critical thinking. As indicated my concern in this paper is more about looking at critical agency and social movements in the South African education system, and I want to use Touraine in this regard. 


\section{Touraine and social movements}

I have chosen to use Touraine in this paper because Touraine's characterisation of social movement is helpful in capturing the shifts in apartheid and post-apartheid struggles, as I will show in this section of the paper. In addition, Touraine's account of social movements, whilst mentioned in other analyses of social movements in South Africa (see Ballard, Habib, Valodia and Zuern, 2013 for example, and which is referred to later in this section of the paper), has not been used sufficiently in the South African context. Carrim and Sayed (1992), however, have used Touraine in their analysis of social movements in the transition from apartheid to the postapartheid situation and in an educational context, and I refer to the analysis they provided in this section of the paper as well.

The purpose of this section of the paper is more to clarify Touraine's account of 'critical' and 'positive struggles', and not so much to review the literature on social movements. I refer to the analyses provided by Ballard et al. (2013), Taylor (1997), Meer (2001) and Hart (2012) of social movements in the postapartheid situation in order to locate Touraine's account of social movements within this body of theories. Ballard et al. (2013), Taylor (1997), Meer (2001) and Hart (2012), however, do not focus on education specifically in their analyses, and as is usually the case, their analyses deal with social movements in general and look at post-apartheid society as a whole.

Ballard et al. (2013) suggest that social movements may be viewed as follows:

\footnotetext{
Social movements are thus, in our view, politically and/or socially directed collectives, often involving multiple organizations and networks, focused on changing one or more elements of the social, political and economic system within which they are located. (Ballard et al, 2013, pg. 2)
}

Social movements, then, are collective forms of action, and not just individual actions, as I indicated at the beginning of this paper. In addition, as Ballard et al. indicate, these collective forms of actions are not any oppositional action but collective forms of actions that are directed. They are directed at 'changing one or more elements of the social, political and economic system'. In the context of this paper, this also means that social movements' collective actions are instances of critical agency - they are directed at changing something - and, they entail critical thinking - being critical about the 
conditions of one's life. It is also important to note that social movements are made up of 'multiple organisations and networks'. This is important to keep in mind because social movements bring together various and varying interests and different types of organisations and enable them to converge on a particular issue.

Ballard et al. (2013) also suggest that:

Taylor (1997) pointed out that mobilisation theory may be viewed as falling into three categories. "These are the dissatisfaction/deprivation approach, the rational approach and the resource mobilisation approach" (Taylor, 1997, p.24). Taylor describes the dissatisfaction/deprivation approach as dealing with people's "experiences of frustration and anger to the relative deprivation brought about by their ... conditions", the rational approach as one which deals with "people who are motivated to engage with citizen action out of individual self-interest and not psychological feelings of deprivation" and the resource mobilisation approach as based on the understanding "that since political dissatisfaction and social conflicts are inherent in every society, the establishment of movements centres on the creation of organisations to mobilise the potential for change" (Taylor, 1997, pp.2-3).

For Ballard et al. (2013), however, social movement theory which includes mobilisation theory may be seen as having three branches: the political opportunity branch, which looks at what kind of political situations construct what kind of protest actions. "The second branch of inquiry investigates how social movement organisations are formed, what local networks they build upon, what existing institutions they employ, and what access they have to political and material resources. This third area of social movement studies is based upon identity-oriented paradigms which stress the importance of social relationships for any understanding of movement activity; they therefore bring cultural frames including shared meanings, symbols and discourses into the analysis"(Ballard et al., 2013, pp.2-4).

My purpose in the above discussion is to point out that there have been, and there are, different ways in which social movements have been conceptualised 
and approaches to social movements have either attempted to combine elements of approaches or to work with such approaches in more a holistic way. Ballard et al. (2013) also suggest a more 'dynamic approach' to social movements which not only uses the insights of other approaches but goes beyond them in order to allow for a more fluid and 'dynamic' sense of social movements in the contexts of globalisation and the transnational character of contemporary social movements.

For me, one of the advantages of using Touraine's characterisation of social movements is that it can be used irrespective of the approach to social movement one adopts. Touraine's characterisation of 'critical and positive struggles' does not prevent any approach to social movements that one may want to adopt. In this regard Ballard et al. (2013), in relation to Touraine, also acknowledge:

\footnotetext{
Analysts of new social movements such as Touraine (1981) and Melucci (1989) have underlined the importance of framing, by focusing on subjective elements such as identity, status and values. Melucci reminds us that the same experiences and behaviour can be viewed in different ways; meanings depend upon systems of reference .These shared meanings, defined as framing processes by Snow and others (Snow et al 1986), are central to any understanding of social movement activity (Ballard et al, 2013, pg. 4).
}

As Ballard et al. indicate above, Touraine's analysis of new social movements, which refers to contemporary forms of social movements, also focuses on 'identity, status and values'. These, as will be seen below, are used in his characterisations of 'critical and positive struggles' and they are useful in viewing the differences in 'critical and positive struggles'. They also help in understanding the shifts from apartheid and post-apartheid formations.

Touraine $(1981,1985)$ distinguishes between what he terms 'critical' and 'positive struggles' in order to capture the characteristics and developments of and within social movements. As indicated above these distinctions are used in this section of the paper to demonstrate the ways in which critical thinking and critical agency have shifted from the apartheid to the post-apartheid moments in South Africa. It is important, though, to first outline what Touraine means by 'critical' and 'positive struggles' before they are applied to the South African educational system. 
Table 1: Touraine's characterisation of types and levels of struggles

\begin{tabular}{|c|c|c|}
\hline & \multicolumn{2}{|c|}{ Types of Struggles } \\
\hline & Positive & Critical \\
\hline Levels of strug & & \\
\hline Institutional & Influence & Access \\
\hline Organisational & Status & Defense \\
\hline Historicity & Alternative & Destroy \\
\hline
\end{tabular}

For Touraine $(1981,1985)$ and in relation to Table 1, 'critical struggles' are acts of defense against crisis, demands of access and attempts to destroy a "truly social domination" (Touraine, 1985, p.90). On the 'institutional' and 'organisational' levels in 'critical struggles' the focus is on getting access to institutions and to defend people rights to be in and to be treated equally within organisations. This is because in 'critical struggles' people are denied access and/or subject to misrecognition and domination within institutions and organisations. Due to these experiences of a 'truly social domination', such critical struggles aim to destroy the existing order of social domination in order to put into place another order, on the level of 'historicity'. This form of a 'truly social domination', of which apartheid was one, provided the focus and framed 'critical struggles'. This is what characterised anti-colonial struggles and is not unique to anti-apartheid struggles. As Osaghae (1990) puts it:

The liberation of the state from colonial hegemony. This was generally true of various nationalist movements, but was truer in those colonies where the independence struggle was "revolutionary" and involved liberation wars (Osaghae, 1990, pg. 15; also cited in Taylor, 1997, pg. 23).

In these 'liberation wars' the aim was to destroy an existing order. There is a vast amount of literature available about the kinds and extent of struggles against apartheid, and there is no need to recount them here. Anti-apartheid struggles covered all sectors of apartheid society, and included an armed struggle which was founded by Nelson Mandela and for which he was imprisoned on Robben Island and the basis to outlaw the then African National Congress, and other political movements, such as the Pan-African Congress, and forced them into exile. 
Looking at apartheid education, in particular, not only did South Africans (and indeed those in the anti-apartheid movement internationally as well) question apartheid education, and exercise critical thinking in relation to what it provided, they also clearly put forward an alternative of a non-racist, nonsexist and democratic educational system for all. This was the case since the beginning of apartheid education with the formation of 'cultural clubs' by the then African National Congress in the 1960s, through to the formation of the National Education Crisis Committee (NECC) and the launching of the People's Education movement in the 1980s to the provision of policy alternatives by the National Education Policy Investigations (NEPI) which was a structure that was formed by the NECC. Various interests and differing political strands were able to converge in such 'critical struggles', and against a 'common enemy' - apartheid (education). It is in this vein that Carrim and Sayed (1992) have also argued that the anti-apartheid struggle, as well as resistances to apartheid education, were within this mold of 'critical struggles'.

In providing such alternatives the anti-apartheid movement was able to demonstrate critical agency at the level of 'historicity' and thus provided significant critical agency that questioned the reproduction effects of apartheid education, the inherent inadequacies with the apartheid order and the inequities of the political economy of apartheid. Central in these developments were the influences of 'reproduction' and 'resistance' theories of schooling (cf. Nkomo, 1990 and Kallaway, 1986) which reinforced ideas about how schooling reproduces inequalities within capitalist societies, and the ways in which educational resistances are enacted.

However, due to the generating of alternatives, the anti-apartheid struggles did not 'destroy' the apartheid order and through the processes of negotiations, through which the post-apartheid dispensation was ushered in, such 'alternatives' were also compromised further and did not quite destroy an old order. This impacted on People's Education and diluted its aims through processes of negotiation and compromise (see Levin, 1991 in this regard).

The politics of negotiations, and the fact that the post-apartheid dispensation is a result of such processes of negotiation, do not make it is easy to simply describe anti-apartheid struggles as clearly defined 'critical struggles'. This is because in relation to the level of 'historicity' (see Table 1 above) critical struggles 'destroy' orders, they do not negotiate with it. The politics of 
negotiations seem to be premised on 'alternatives' since it is 'alternatives' that one brings to the table, as it were, when one negotiates. Negotiations, then, and the politics thereof, are more within 'positive' and not 'critical struggles', at the level of 'historicity'.

'Positive struggles' for Touraine $(1981,1985)$ and in relation to Table 1, are when people generally have access to social goods and institutions and where the social formation is not characterised by blatant forms of domination and oppression. 'Positive struggles', then occur mostly in democratic societies. However, struggles in these democratic societies are more about the extent people have 'influence' within 'institutions', the 'status' they occupy within 'organisations' and the degree to which they are able to enact 'alternative' ways of being and thinking. In 'positive struggles' then, position, positionality and impact matter most in order to construct alternative orders. Ballard (2005) usefully captures this shift to 'positive struggles' in the South African context in the following:

\begin{abstract}
Whereas the need for adversarial struggle for state capture against the illegitimate apartheid state was clear, such unity of purpose does not emerge in the context of a democratically elected government. Today's social movements are no longer affiliated to a political party working towards the capture of the state, as was the case prior to the democratic transition. Oppositional movements of the democratic era are more fragmented on what it is that they oppose and what their political project is. Opponents of the state have to overcome the familiarity that characterises the postcolonial situation (Ballard, 2005, pg. 1).
\end{abstract}

The postcolonial situation, to which Ballard refers, has been viewed by many as struggles around (re)defining 'the nation' - a nation borne out of anticolonial struggles, and whose identity needs to be forged. As Osaghae (1990) also notes:

Since attaining independence, the liberation goal has been directed towards neocolonialism ... the forging of national unity ... Overcoming under-development, especially in the economic sphere (Osaghae, 1990, pg. 15; also cited in Taylor, 1997, pg. 23).

In Gramsci's terms such contestation around 'forging national unity' are 'struggles of hegemony', and are complex and dynamic. They involve various interests and various actors, operating on various levels and in several spaces. Touraine's characterisation of 'positive struggles' is useful in this regard because it gives one a sense of where and how such struggles occur. 'Positive struggles' in these postcolonial, democratic societies are more about the extent people have 'influence' within 'institutions', the 'status' they occupy 
within 'organisations' and the degree to which they are able to enact 'alternative' ways of being and thinking, as a new nation is constructed.

Using a Gramscian lens, Hart (2012) notes:

The hegemonic project of the ANC government hinges crucially on official articulations of nationalism and claims to moral authority through leadership of the liberation movement.

Tapping into popular understandings of freedom, justice, and liberation from racial oppression and racialized dispossession, official articulations of nationalism bolster the ruling bloc's hegemonic project in crucially important ways. At the same time these articulations are vulnerable to counterclaims of betrayal - and to the reclaiming of popular understandings of what is embodied in "the national question." Escalating popular struggles over the material conditions of life and livelihood over the past decade are simultaneously struggles over the meanings of the nation and liberation - struggles that can and do move in different directions (Hart, 2013, pg 316).

Carrim and Sayed (1992) also suggest that the post-apartheid formation is more characterised by such 'positive struggles' since in the post-apartheid formation, which is a democratic dispensation, people are no longer denied access as was the case under apartheid. People can now contest the extent to which they exercise influence, the status that they have and the extent to which they can meaningfully construct alternative orders; all of which are constantly struggled over and contested by various people with varying interests.

Using the above as a lens with which to view the shifts in critical thinking and critical agency from apartheid to the post-apartheid situation it is evident that in positive struggles, which predominate in the post-apartheid situation, the emphasis is on engaging with existing institutions, organisations and orders rather than being fundamentally opposed to them. The emphasis, thus, on the level of 'historicity' is about enacting an 'alternative' and not to 'destroy' orders.

The question that arises from the above discussion is whether the type of critical agency that was demonstrated in the anti-apartheid struggles is possible within the post-apartheid situation. Put differently, and in Touraine's terms, how does one exercise critical agency in 'positive struggles' as opposed to 'critical struggles'? In order to explore possible answers to this question in the following I use the example of Equal Education, an organisation that emerged in the post-apartheid situation and which seems to manifest characteristics of both 'critical' and 'positive struggles'. 


\section{Critical agency in post-apartheid South African Education}

Equal Education (EE) describes itself as:

Equal Education is a movement of learners, parents, teachers and community members working for quality and equality in South African education, through analysis and activism (http://www.equaleducation.org.za/ accessed 23 July 2014 at 15H00).

EE has monitored the activities of the post-apartheid education ministry and has consistently pointed to the ongoing denial of education rights to many South African learners by the post-apartheid's government failure to ensure access to education among the poorest of the poor; the lack of basic facilities in schools located in mainly under-developed rural areas, lack of sanitation, electricity and other basic facilities in such schools; and, the lack of adequate teaching and learning materials in such schools. EE has grown in national stature and its constituency extends all provinces in South Africa. The current campaign of EE is related to ensuring that the Department of Basic Education (DBE) in South Africa establishes and implements minimum norms and standards for school infrastructure. The norms and standards for school infrastructure was the focus of the conference held by EE in July 2014 in Johannesburg.

EE has petitioned government, made various submissions to the DBE, threatened legal action against the DBE, embarked on many protest marches in all provinces in the country and hosted several public meetings to highlight the plight of those schools who, even in the democratic South Africa, continue to suffer the indignities of lack of access to basic school facilities and thus are denied to fully realise their rights to basic education.

In the light of the above it is fair to state that EE meets the criteria of a social movement as outlined by Ballard et al. (2013) and which was cited earlier in this paper. EE is 'directed' and focuses on a 'single element' within the system. EE also is made up of various types of actors in different organisational structures across the country.

EE also carries with it a 'critical struggle' dimension in that it continues with the quest to ensure access to basic and quality education for all - this is continuous with the same demands that were made by the anti-apartheid movement, as discussed above. The focus on access is one of the central 
demands in 'critical struggles' on 'institutional' and 'organisational levels'. EE also 'defends' the right to educational access. In doing so, EE also highlights the fact that the new post-apartheid educational system is not working for all.

However, EE also manifests dimensions of 'positive struggles'. In the July 2014 conference, the EE states:

The Norms \& Standards for School Infrastructure require all provincial departments to submit implementation plans to the Minister of Basic Education by 29 November 2014. The Conference will discuss how, where possible, to support the provinces in the preparation and the implementation of those plans (EE Conference, Fixing our Schools 1415 July, Conference Programme, pg. 9).

Later in the same conference programme EE states:

Much needs to be done by government, and with the support of civil society and other sectors a lot can be achieved. To monitor what is happening in all nine provinces, and to support implementation, is going to take a collective effort, and a shared strategy going forward is crucial to ensure that adequate school infrastructure becomes a reality for thousands of schools. This Norms and Standards Implementation Conference is geared towards those ends (EE Conference, Fixing our Schools 14-15 July, Conference Programme, pg. 9).

In relation to the above quotations three things become evident about EE: 1) it is located in civil society; 2) its concern is about helping government, the DBE in this instance, about doing things right and for all; and 3) it shifts to partnership with government, as opposed to being critical agents against government. EE, thus, enters into more 'positive struggles' types of action which aim at increasing their influence and status with and within government. This also renders its potential for generating alternative ways and modes of being minimal.

However, what more could EE be expected to do in the post-apartheid situation other than engage in 'positive struggles' that focus on the extent of their influence and status within government and within the educational postapartheid system and community?

Ballard very poignantly points out:

Struggles in post-apartheid South Africa respond, in the first instance, to particular manifestations of exclusion, poverty and marginality. They are very often local and immediate; they are pragmatic and quite logical responses to everyday hardships. Activists 


\begin{abstract}
operate to achieve direct relief for marginalised groupings on particular issues. Such activists do not focus primarily on opposing the state's economic path, although they may do so by default, but rather on more specific struggles. This is not to say that they necessarily agree with the current national programme but rather that they choose to focus their attention on particular gains in relation to particular issues. In such situations, engagement with the state may indeed be on the cards. The country has, after all, installed a democratically elected government and given it an overwhelming mandate to pursue its programmes for overcoming the injustices of apartheid (Ballard, 2005, pg. 3).
\end{abstract}

This situation raises a few important questions about the extent to which even the actions of EE can be considered as critical agency. If actions taken do not project an alternative at the level of 'historicity' then neither in 'critical struggles' nor 'positive struggles' can they be considered to be actions of critical agency. Part of the issue here is that the post-apartheid government as opposed to the apartheid government is not a clearly defined 'enemy'.

It is precisely because of this that movements like the EE cannot easily project the post-apartheid government as an entity it simply cannot enter into partnership with. But, as should be clear from the discussion above, EE is at best in a critical partnership (a notion that began to be increasingly used since 1996 in South Africa) with government.

The lack of a clearly defined 'enemy', however, speaks to pluralisation of spaces and actions and actors in the postmodern situation, not only in South Africa but internationally as well. The complexity of postcolonial struggles also reverberates with the postmodern situation. It is to these dimensions and their impact on critical agency that I now turn attention.

\title{
Critical agency and the postmodern condition
}

The pluralisation of spaces, actors and actions possible in the postmodern condition is due to several levels of developments. Although it is not possible in this section of the paper to outline in detail the characteristics of this postmodern condition, briefly it may be seen in the following terms. The postmodern condition opens up spaces on the economic, political and sociocultural levels.

In economic terms the ascendency of the global economy, which is currently cast in neo-liberal terms, has impacted on the conditions of people work and is driven by the internet (cf. Castells, 2001). Politically, this has resulted in 
supranational organisations and forms of democratic participation which have both increased the spaces for various interests and difference to rise. A 'politics of difference' and/or a 'politics of identity' has thus come to fore (see Melluci, 1989), with various assertions of identities organised in social movements ranging from various religious groups, feminist movements, sex/ual orientation focused movements, anti-privatisation groups, environmental groups and so on. If one needs to get a sense of plurality of movements, interests and actors there are in post-apartheid South Africa in relation to this, then the following should suffice:

\footnotetext{
The new generation of social movements appeared in earnest once the ANC's second term in office began. The Treatment Action Campaign (formed in 1998), Concerned Citizens Forum (1999), Anti-Eviction Campaign, Anti Privatisation Forum, Soweto Electricity Crisis Committee (2000), the Landless Peoples Movement, Coalition of South Africans for the Basic Income Grant (2001) and the Education Rights Project (2002), have been amongst the more enduring and visible struggles to have reconstituted a vibrant oppositional civil society. Countless unnamed small scale and ephemeral struggles have also emerged across the country (Ballard, 2007, pg. 6).
}

In these political developments the types of oppositional actions that seem to predominate seem to be more in terms of alliances that are formed and which are enacted in terms of 'front' politics where people with various interests converge momentarily in a 'front' as a temporary 'alliance' which lasts only in relation to a particular issue that has been identified as in need of reactions and oppositions. Soon thereafter such alliances dissipate. Crucial to note in this is the transitory character of such collective forms of action (see also Melucci, 1985; and, Brandt, 1986).

On socio-cultural levels, ways of being and thinking are also being pluralised in terms of various and varying forms of identities and which also play themselves out in cyberspace. In this scenario, it becomes difficult to identify a clear 'enemy' and to mobilise collective forms of actions that would endure beyond a specific moment.

It is at this point, then, one is forced to rethink what in fact critical agency could mean within such a situation, of which the post-apartheid situation is a part.

I have argued in this paper that the beginning of critical agency is the development of critical thinking, but critical thinking on its own does not constitute critical agency. In the light of this, the post-apartheid education system needs to at least be viewed critically, and critical thinking about what 
it does and does not do, in relation to what and in which terms will need to be enabled and encouraged. Without this any potential for critical agency will be difficult to put into place.

But this critical thinking needs to be more substantive than merely being critical about the extent to which government in fact realises its own policies in implementation. It will need to seriously interrogate which ways of being, whose forms of thinking and what types of actions and order it promotes. It cannot only be about the extent to which government implements its own policies.

The overwhelming tendency to enter into partnership with government, as is also the case with EE as discussed above, have led some to suggest that implicit in such partnerships with government is a de-mobilisation of civil society. Meer (2001) has, for example, argued that it is not only critical agency that is being undermined but the effects of current post-apartheid hegemonic processes is to appropriate civil society organisations and thereby de-mobilise civil society itself. Hart (2012) has also suggested that it may be useful to conceptualise these constraints on critical agency as akin to Gramsci's notion of 'passive revolution'.

This then leads to the points I raised and arguments I made in other sections of this paper. Critical agency in contexts where a clearly defined 'enemy' is not present, where a 'truly social domination' does not exist, can only mean what individuals can do in dispersed and pluralised spaces of their lives. Such forms of critical agency will include exercising critical thinking about the ideologies to which they are subjected, the ways in which they are positioned and the ways in which their ways of being are circumscribed and/or proscribed. These forms of critical agency at individual levels will be about contesting the hegemonic orders that influence their lives. Such critical agency could range from contesting the limits of structures; the ways in which such structures constitute and are constituted; the extent to which difference is acknowledged; the types of epistemic worldviews that are assumed; to modes of representation and modes of participation that are promoted.

However, it should be made clear that such individual forms of critical agency will not necessarily cohere into a collective social movement or a collective form of action. As I indicated above, the possibilities for such collective forms of actions will, in the postmodern condition, be in 'front politics' form and will be about people coming into an alliance around a particular issue for 
a specific period of time. Thus, collective action possibilities would be transitory and issue based. In these forms of collective actions what should be noted is: 1) they are about a particular issue or event; 2) they are global alliances; 3) local and individual actions are rearticulated in terms of the issue being targeted and linked to the alliance; 4) the alliance disappears when the issue is over; and, 5) actors in each alliance may not necessarily be the same.

The implications of what has been discussed above is that critical agency in the current situation requires a critical understanding of one's own situation and an awareness of global connections. Critical agency also needs to focus on not only local but global socio-cultural and political economies. Thus, with the pluralisation of spaces in the postmodern and postcolonial conditions, possibilities for critical agency at individual and local levels increase, and at the same time it suggests that alternative struggles at the level of 'historicity' are more likely to be global in character. It should be kept in mind that the individual and local in relation to the global are not in bipolar opposition but need to be viewed as being dialectically inter-related. The global influences the local and vice versa.

In concluding this section of the paper, it is important for me to point out that what in fact constitutes 'alternatives' at the level of 'historicity' in Touraine's terms and the actual possibilities (and desirability) of 'destroying' existing orders may need to be revisited. Part of the difficulty with this is the absence of a clearly defined enemy, as I have argued. Another part of the complexity surrounding this is also that the level of 'historicity' implies a type of metanarrative. Such meta-narratives are critiqued and/or denied in both postmodern theorising and conditions (see for example Hall, 1992; and Usher,1996, in this regard). It is, thus, difficult to understand what the centrifugal force constructed through such meta-narratives and which allow struggles to cohere at the level of historicity could mean under such postcolonial and postmodern conditions. I have suggested above that one form this could take is in 'front politics' but these are transient. Further engagement with this will be necessary in order to get a better understanding of critical agency may mean in current times.

Finally, I also need to indicate that Touraine's typology of 'critical and positive struggles' which I have used in this article cannot be viewed as clearly separated from each other. I have shown that EE manifests both elements of 'critical and positive struggles'. Touraine's typology, thus, remains useful if viewed as over-lapping with each other, rather than being 
distinct. This seems to be more the case in postcolonial contexts, where legacies of neo-colonialism to which Mbembe (2001) and Osaghae (1990) refer. In such postcolonial contexts, as in South Africa, where legacies of apartheid persist whilst constructing a post-apartheid order, 'critical and positive struggles' could, as I have shown with EE, operate simultaneously. In this regard, then, I think it will be necessary to realise that critical agency will be continuous with past forms of 'critical struggles'. Critical agency will be also different and discontinuous with 'critical struggles' as it is (re)defined and (re)articulated in complex contemporary pluralised societies. What critical agency could mean under such conditions, and in 'positive struggles', will also need further engagement.

\section{Conclusion}

The primary focus in the paper has been to look at what could be considered to be social movements using critical agency in a post-apartheid situation and the extent to which such social movements may be considered to be leading to alternative social orders. I have argued in this paper is that the post-apartheid situation seems to be more characterised by 'positive struggles' and issues of influence and positioning seem to predominate. Whilst such positive struggles reflect both critical thinking and critical agency they do not necessarily lead to alternatives at the level of 'historicity'. Looking at Equal Education (EE), I have shown that EE represents a type of social movement in the postapartheid educational system that manifests both 'critical' and 'positive struggles', and as such demonstrates a critical agency at moments, but, at other moments, it also manifests tendencies to reinforce the construction of a dominant existing order in its partnerships with government. In this regard, I have argued that the limitations of what may possible to movements such as EE reverberate with the constraints of collective socio-political action in postmodern and postcolonial conditions. In relation to postmodernity and post-colonialism, I have been pointed out that collective actions tend to be more in the form of 'front politics' which utilise alliances among various people and groupings, with varying and multiple interests. Such alliances also tend to be transient and issue focused. In such a scenario, social movements against a 'truly social domination' seem to be less possible. I have also pointed out in this paper that what may be seen to constitute alternatives at the level of 'historicity' in such post-apartheid and postmodern conditions needs to be explored in further serious debate and discussion, since moving towards 
more just social orders, locally and internationally, depend on such theories to inform future critical agency.

\section{References}

Aronowitz, S. and Giroux, H. 1986. Education under siege. Massachusetts: Bergin and Harvey Publishers, pp.69-114.

Ballard, R. 2005. Social movements in post-apartheid South Africa. An introduction. In Jones, P. and Stokke, K. (Eds), The politics of socio-economic rights in South Africa. The Hague: Martinus Nijhoff, pp.1-20.

Ballard, R., Habib, A., Valodia, I. and Zuern, E. 2013. Globalization, marginalization and contemporary social movements in South Africa. African Affairs, 104(417): pp.615-634.

Brandt, K. 1986. New social movements as a metapolitical challenge: the social and political impact of a new historical type of protest. Thesis Eleven, 15(1): pp.60-68.

Bourdieu, P. 1976 The school as a conservative force: scholastic and cultural inequalities. In Dale, R., Esland, G. and MacDonald, M. (Eds), Schooling and capitalism. London: Routledge and Kegan Paul Ltd, pp.110-118.

Bowles, S. and Gintis, H. 1976. Schooling in capitalist America. New York: Basic Books.

Carrim, N. and Sayed, Y. 1992/1993. Civil society, social movements and the National Education Co-ordinating Committee (NECC). Perspectives in Education, 14(1): pp.21-34.

Castells, M. 2001. The new global economy In Muller, J., Cloete, N. and Badat, S. (Eds), Challenges of globalisation: South African debates with Manuel Castells. Cape Town: Maskew Miller Longman.

Christie, P. and Collins, C. 1986. Bantu education: apartheid ideology and labour reproduction. In Kallaway, P. (Ed.) Apartheid and education. Braamfontein: Ravan Press, pp.160-183. 
Craib, I. 1984. Modern social theory: from Parsons to Habermas. Brighton: Wheatsheaf Ltd, Harvester Press.

Dale, R., Esland, G. and MacDonald, M. (Eds). 1976. Schooling and capitalism. London: Routledge and Kegan Paul Ltd.

Dewey, J. 1910. How we think. New York: D C Heath and Co. Publishers.

Equal Education, 2014. EE Conference, Fixing our Schools, 14-15 July, Conference Programme.

Hahn, H., Carnap, R. and Neurath, O. 2001. The scientific conception of the world: the Vienna Circle. In Linderberg, J.J. (Ed), Analytic philosophy: beginnings to the present. Mayfield CA: Mayfield Publishing Co., pp.147-166.

Hall, S. 1992.The question of cultural identity. In Hall, S., Held, D. and McGrew, T. (Eds), Modernity and its futures. Cambridge: Polity Press, pp. $274-291$.

Hart, G. 2012. Gramsci, geography and the languages of populism. In Eckers, M., Hart, G., Kipfer, S. and Loftus, A. (Eds), Gramsci: space, nature and politics. West Sussex: John Wiley and Sons Publishers, pp.301-319.

Hospers, J. 1990. An introduction to philosophical analysis. 3rd Edition. London: Routledge and Kegan Paul Ltd.

Kallaway, P. 1986. Apartheid and education. Braamfontein: Ravan Press.

Levin, R. 1991. People's education and the politics of negotiation. Perspectives in Education, 12(2): pp.1-18.

Marx, K. and Engels, F. 1969. Selected works; Volume 1. Moscow: Progress Press.

Mbembe, A. 2001.On the postcolony. Berkeley and LA: University of California Press.

Meer, S. 2001. The demobilization of civil society: struggling with new questions. Development Update, 3(1): pp.1-8. 
Melucci, M. 1985. The symbolic challenge of contemporary movements. Social Research, 52(4): pp.789-816.

Melucci, A. 1989. Nomads of the present. London: Hutchinson.

Molteno, F. 1987. Students take control: the 1980 boycott of coloured education in the Cape Peninsula. British Journal of Sociology of Education, 8(1): pp.27-51.

Nkomo, M. 1990. Pedagogy for domination. Trenton: Africa World Press.

Osaghae, E.E. 1990. Social mobilization as a political myth in Africa. Africa Quarterly, 30(3-4): pp. 8-23.

Plato, 1920.The republic $3^{\text {rd }}$ Edition. New York: Random House.

Taylor, V. 1997. Social moblisation: lessons from the mass democratic movement. Cape Town: F.A Print.

Touraine, A. 1981. The voice and the eye: an analysis of social movements. Cambridge: Cambridge University Press.

Touraine, A. 1985. An introduction to the study of social movements. Social Research, 52(4): pp.85-98.

Usher, R. 1996. A critique of the neglected epistemological assumptions of educational research. In Scott, D. and Usher, R. (Eds), Understanding educational research. London: Routledge, pp.9-32.

Willis, P. 1981. Learning to labour. New York: Columbia University Press.

Wolpe, H. 1988. Race, class and the apartheid state. London: James Curry Publishers.

\section{Website}

http://www.equaleducation.org.za/ 
Nazir Carrim

Division of Studies Education

Wits School of Education

nazir.carrim@wits.co.za 